Original Research Paper

\title{
Seasonal Variations in Semen Quality of Pasundan Bulls in their Native Tropical Environment
}

\author{
1*Nurul Isnaini, ${ }^{2}$ Tri Harsi, ${ }^{1}$ Anggit Damaratri Lapoliwa, \\ ${ }^{1}$ Muhammad Mas'ud Chabiburochman and ${ }^{1}$ Abimarhadimas Dwi Amarsyah \\ ${ }^{I}$ Department of Animal Production, Faculty of Animal Science, Brawijaya University, Malang, Indonesia \\ ${ }^{2}$ Lembang Artificial Insemination Center, Bandung, Indonesia
}

\author{
Article history \\ Received: 09-03-2021 \\ Revised: 15-04-2021 \\ Accepted: 20-04-2021 \\ Corresponding Author: \\ Nurul Isnaini \\ Department of Animal \\ Production, Faculty of Animal \\ Science, Brawijaya University, \\ Malang, Indonesia \\ Email: nurulisna@ub.ac.id
}

\begin{abstract}
The success of artificial insemination highly depends on the semen quality, in which it may significantly associate with the environmental factor. However, the information regarding the seasonal effects on semen quality of Pasundan bulls is still scarce. This study aimed to examine seasonal variation in semen quality of Pasundan bulls in their native environment. A total of 203 ejaculates produced by two Pasundan bulls aged at four years old were used in this study. The bulls were kept under standard management conditions in Lembang Artificial Insemination Center. The results showed that mean values of semen volume, sperm concentration, total sperm number, individual sperm motility, post-thawing sperm motility and frozen semen production of Pasundan bulls were $5.7 \mathrm{~mL}, 1.17$ billion/ml, 6.57 billion/ejaculate, $62.1,040.6$ and 272\% doses/ejaculate, respectively. Semen volume, individual sperm motility and post-thawing sperm motility were not affected by different seasons $(\mathrm{P}>0.05)$. Whereas, the significant reduction of sperm concentration $(\mathrm{P}<0.05)$, total sperm number $(\mathrm{P}<0.01)$ and frozen semen production $(\mathrm{P}<0.01)$ were observed in the dry season as compared to the rainy season. The minor change in ambient temperature, maximum ambient temperature, relative humidity and temperature-humidity index were detected between seasons. On the other hand, about $52 \%$ greater sunshine duration was detected in the dry season compared to the rainy season. In conclusion, the semen quality of Pasundan bulls is reduced during the dry season, which is considerably associated with the increase in sunshine duration.
\end{abstract}

Keywords: Artificial Insemination, Heat Stress, Indonesian Native Cattle, Semen Cryopreservation, Sunshine Duration

\section{Introduction}

Beef is a nutrient-dense food that provides essential amino acids, vitamins, minerals and bioactive components for humans (Mwangi et al., 2019). Beef consumption is highly crucial for humans to support optimal physiological development and intellectual performances (Ribas-Agustí et al., 2019). Recently, beef demand in Indonesia is increased year by year. In 2009, beef consumption by Indonesian society was 0.31 $\mathrm{kg} / \mathrm{capita} /$ year, while in 2018 , the beef consumption was increased up to $0.47 \mathrm{~kg} / \mathrm{capita} /$ year (DGLAH, 2014; 2018). It could be calculated that there was a $51.61 \%$ increase in beef demand during 2009-2018. Additionally, (CDISA, 2017) predicted that national beef demand in Indonesia in 2022 would increase by $8.15 \%$ as compared to the beef demand in 2018. However, the high Indonesian national beef demand is still cannot be fulfilled by the productivity of local cattle. As stated by (Agus and Widi, 2018), about 55\% of beef demand is still supplied from imported cattle. This condition mostly due to the relatively low population of local cattle so that they could not produce enough beef for society. Hence, the use of biotechnology becomes a crucial strategy to increase the local cattle population.

Artificial Insemination (AI) currently becomes the most accepted reproductive biotechnology applied in the livestock. The procedure of AI includes three main steps, namely semen collection from the male sire, semen processing and semen insemination into the female reproductive tract (Mohammed, 2018). The beneficial effect of AI, including improve fertility, increase the 
genetic potential of offspring, as well as reduce disease transmission among livestock, in which those benefits could, in turn, ultimately affect economic profit for farmers (Moore and Hasler, 2017). Additionally, the goal of this reproductive technology is to generate more offspring with a higher growth rate so that they could produce higher meat production.

The success of AI highly depends on the semen quality, in which it may significantly associate with the environmental factor. In the temperate region, photoperiod (time interval between sunset and sunrise) is the most responsible factor affecting seasonal variation in semen quality (Snoj et al., 2013). While in the tropical region, since the photoperiod is almost similar throughout the year, other factors such as temperature and relative humidity probably become two significant contributors in the semen quality variation (de Castro et al., 2017). In more recent, sunshine duration, which defined as the duration of direct sunshine exposure to the land surface, also reported as one factor which could influence semen quality (Golher et al., 2018). All of these-mentioned factors should be discussed to provide in-depth knowledge of seasonal effects on semen quality.

Pasundan cattle is officially registered as one of the Indonesian-origin breeds (Ministry of Agricultural Decree Number: 1051/Kpts/RI/SR.10/2014). These cattle were originally the result of crossbreeding between Bali cattle (Bos javanicus) and Ongole and Madura cattle (Bos indicus), which was conducted in 1904 (Said et al., 2017). The distribution of this cattle mainly in the West Java area, including Ciamis, Cianjur, Garut, Indramayu, Kuningan, Majalengka, Pangandaran, Purwakarta, Sukabumi, Sumedang and Tasikmalaya Districts (Sulasmi et al., 2017). Pasundan cattle had a solid reddish-brown coat with the presence of black color on the hoof, switch of the tail, eyelid, muzzle and horn, as well as whitish color on mouth lash and light brown color on legs (stocking) and rump patch (Said et al., 2017). Moreover, it was also reported that adult male Pasundan cattle had the average body length, withers height, chest girth and scrotal circumference of $129,129,159$ and $18 \mathrm{~cm}$ respectively. On the other hand, female adult Pasundan cattle had 116, 123 and $140 \mathrm{~cm}$, respectively (Said et al., 2017). The carcass yield of Pasundan cattle was approximately 53\% (Sulasmi et al., 2017). According to (Sutarno and Setyawan, 2015), Pasundan cattle is easy to adapt to extreme weather and has high resistant to tropical diseases. Additionally, (Setiawati et al., 2018) reported that Pasundan cows had sexual maturity, age at first mating, gestation length, age at first calving and calving interval of $21,23,9-10,33$ and 14 months, respectively. However, the information regarding the seasonal effects on semen quality of Pasundan bulls is still scarce. For that reason, this study was conducted to clarify the effect of the rainy and dry seasons on semen quality of Pasundan bulls in their native tropical environment.

\section{Materials and Methods}

\section{Study Area}

This study was conducted at the Lembang AI center (Bandung, West Java Province, Indonesia). This area was located at $6^{\circ}$ south latitude and $107^{\circ}$ east longitude. The altitude of this area was $1,241 \mathrm{~m}$ above mean sea level.

\section{Animals and Experimental Design}

For the purpose of the study, 2 Pasundan bulls (4 years old) were used as AI donors. The bulls were reared under standard management practice in the Lembang AI center. Each bull was kept in an open-sided cage with a size of $4 \times 2.5 \times 2 \mathrm{~m}$ (length, width and height, respectively). The feed consisted of $1 \mathrm{~kg}$ hay of Africa grass, $50 \mathrm{~kg}$ fresh forage of elephant grass, $4 \mathrm{~kg}$ concentrate feed and $0.5 \mathrm{~kg}$ fresh sprout of mung bean. The total digestible nutrient and crude protein contents of the concentrate feed were 65 and $16 \%$, respectively. The drinking water was provided ad libitum. The semen was collected from each bull using an artificial vagina (Kruuse, model 340284, Denmark). The semen collection was done for two years from 2017 to 2018 , resulting in 89 ejaculates in the rainy season and 114 ejaculates in the dry season.

\section{Semen Quality Evaluation}

The semen quality was measured directly upon collection, including semen volume, sperm concentration, total sperm number, individual sperm motility, post-thawing sperm motility and frozen semen production. The semen volume was measured using a scaled vial (Isnaini et al., 2019a). Sperm concentration was measured using the spectrophotometric method (Isnaini et al., 2019a). The total sperm number was calculated by semen volume $\mathrm{x}$ sperm concentration (Isnaini et al., 2019a). The individual sperm motility and post-thawing sperm motility were assessed under a light microscope at 400 $\times$ magnification (Susilawati et al., 2018). Frozen semen production was calculated according to the Indonesian National Standard (SNI 4869-1:2008, 2008) with the formula of total sperm number/ 25 million sperm.

\section{Climate Factors}

The climate factors, including mean ambient temperature, maximum ambient temperature, relative humidity and sunshine duration, were collected from the local climatological office near the bull station. Temperature-humidity index was calculated by $0.8 \times$ mean ambient temperature + (relative humidity/100) $\times$ (mean ambient temperature-14.4) +46.4.

\section{Data Analysis}

The statistical procedure was performed using SPSS software for Windows, version 13.0 (SPSS Inc., Chicago, 
IL, USA). Analysis of variance was employed to evaluate semen quality variation between rainy and dry seasons. Data were expressed as mean \pm Standard Error $(\mathrm{SE})$ followed by $\mathrm{P}$-value on each semen quality. $\mathrm{P}<0.05$ was stated as a significant difference.

\section{Results and Discussion}

The mean values of semen volume, sperm concentration, total sperm number, individual sperm motility, post-thawing sperm motility and frozen semen production of Pasundan bulls were $5.70 \mathrm{~mL}, 1.17$ billion/ml, 6.57 billion/ejaculate, 62.10, 40.60 and $272 \%$ doses/ejaculate, respectively. Table 1 shows that the semen volume, individual sperm motility and post-thawing sperm motility were not affected $(\mathrm{P}>0.05)$ by different seasons. On the other hand, the significant change in sperm concentration $(\mathrm{P}=0.049)$, total sperm number $(\mathrm{P}=0.006)$ and frozen semen production $(\mathrm{P}=0.005)$ were observed during the rainy and dry seasons. In the dry season, Pasundan bulls had 8.13, 14.03 and $14.24 \%$ lower sperm concentration, total sperm number and frozen semen production, respectively, as compared to the rainy season.

The minor changes in mean ambient temperature, maximum ambient temperature, relative humidity and temperature-humidity index were detected in this study (Table 2). The variation coefficient of monthly mean values of mean ambient temperature, maximum ambient temperature, relative humidity and temperature-humidity index were $1.60,2.16,5.78,0.93 \%$ respectively. On the other hand, sunshine duration was found to be varied between seasons, with about $52 \%$ greater sunshine duration was detected in the dry season compared to the rainy season.

The results of the semen quality of Pasundan bulls obtained in this study were slightly higher as compared to other Indonesian native cattle. Previously, (Isnaini et al., 2019b) found that Bali bulls had semen volume, sperm concentration, total sperm number, individual sperm motility, post-thawing sperm motility and frozen semen production of $4.81 \mathrm{~mL}, 1.11$ billion $/ \mathrm{ml}, \quad 5.37$ billion/ejaculate, 68.8, 43.9 and $215 \%$ doses/ejaculate. Nugraha et al. (2019) reported that semen volume, individual motility and sperm concentration of Bali bulls were $4.90 \mathrm{~mL}, 62.5$ and $1.07 \%$ billion $/ \mathrm{ml}$. In another study, (Yekti et al., 2018) showed that Madura bulls had semen volume and sperm concentration of $4.57 \mathrm{~mL}$ and 1.07 billion/ml, respectively. Additionally, frozen semen production of Pasundan bulls in this study was comparable to that of Simmental bulls reared in tropical climate conditions, which had frozen semen production of 277 doses/ejaculate (Isnaini et al., 2019b). However, the semen quality of Pasundan bulls was inferior to that of Holstein bull at the same age, which had semen volume, sperm concentration and frozen semen production of $7.52 \mathrm{~mL}, 1.24$ billion $/ \mathrm{ml}$ and 349 doses/ejaculate (Argiris et al., 2018).

In this study, it was found that sperm concentration, total sperm number and frozen semen production were altered during different seasons. In agreement with this finding, (Prastowo et al., 2018) also reported that the season could alter semen quality of Bali bulls.

Similarly, it was also found that the semen quality of Ongole grade cattle was changed during rainy and dry seasons (Suretno et al., 2018; Isnaini et al., 2019c). In another study, (Nichi et al., 2006) also found that the season could alter semen quality of Simmental bulls in tropics. Landaeta-Hernández et al. (2020) also reported that the seasons significantly affect semen quality of Bos indicus, Bos taurus, Crossbred Bos taurus x Bos indicus and tropically adapted Bos taurus composites bulls. Nongbua et al. (2020) also detected the variation of semen quality of Bos indicus bulls among different seasons in Thailand.

Table 1: Effects of season on semen quality of Pasundan bulls

\begin{tabular}{llll}
\hline Parameters & Rainy & Dry & P-value \\
\hline Semen volume (ml/ejaculate) & $5.87 \pm 0.17(89)^{\mathrm{a}}$ & $5.57 \pm 0.17(114)^{\mathrm{a}}$ & 0.218 \\
Sperm concentration (billion/ml) & $1.23 \pm 0.04(89)^{\mathrm{b}}$ & $1.13 \pm 0.03(114)^{\mathrm{a}}$ & $<0.05$ \\
Total sperm number (billion/ejaculate) & $7.13 \pm 0.29(89)^{\mathrm{b}}$ & $6.13 \pm 0.22(114)^{\mathrm{a}}$ & $<0.01$ \\
Individual sperm motility (\%) & $62 \pm 1.61(89)^{\mathrm{a}}$ & $62.2 \pm 1.28(114)^{\mathrm{a}}$ & 0.911 \\
Post-thawing sperm motility (\%) & $40.4 \pm 0.18(60)^{\mathrm{a}}$ & $40.8 \pm 0.24(74)^{\mathrm{a}}$ & 0.203 \\
Frozen semen production (doses/ejaculate) & $295 \pm 12.2(60)^{\mathrm{b}}$ & $253 \pm 8.59(74)^{\mathrm{a}}$ & $<0.01$ \\
\hline
\end{tabular}

Values are expressed as means \pm SE followed by the number of ejaculates in parenthesis ${ }^{\mathrm{ab}}$ Means with uncommon superscripts within the same row differ significantly

Table 2: Summary of environmental conditions during the study

\begin{tabular}{lll}
\hline Parameters & Rainy & Dry \\
\hline Mean ambient temperature $\left({ }^{\circ} \mathrm{C}\right)$ & $23.6(23-24.3)$ & $23.5(22.9-24)$ \\
Maximum ambient temperature $\left({ }^{\circ} \mathrm{C}\right)$ & $29.1(27.8-29.6)$ & $29.6(28.7-30.5)$ \\
Relative humidity $(\%)$ & $79.3(74.4-81.9)$ & $73.4(67.2-78.8)$ \\
Temperature-humidity index & $72.6(71.8-73.1)$ & $71.9(70.4-73)$ \\
Sunshine duration (minutes) & $265(172-318)$ & $389(274-498)$ \\
\hline
\end{tabular}

Values are expressed as means followed by minimum and maximum values in parenthesis 
In the previous studies, it was reported that the change in semen quality was much associated with mean ambient temperature, maximum ambient temperature, relative humidity and temperature-humidity index (Bhakat et al., 2011; Chacur et al., 2013; Valeanu et al., 2015; Sabés-Alsina et al., 2017; Sabés-Alsina et al., 2019). However, in this study, those climate factors were almost equal during rainy and dry seasons. For that reason, it could be stated that the change in semen quality in the present study was not as a reflection of those factors.

The marked variation on sunshine duration probably more relevant to explain the reduction of semen quality of Pasundan bulls found in this study. This result was corroborated by (Perumal et al., 2017), who also found that the semen quality was decreased when collected at the season which had higher sunshine duration. The high sunshine duration had an indirect effect on semen quality through the elevation of solar radiation. In this study, Pasundan bulls were kept in the open-sided cage so that the solar radiation may reach them, thus inducing heat stress (Herbut et al., 2018). Additionally, Pasundan bulls used in this study had a black coat color. The body coat color of Pasundan bulls could change from solid red to black. This phenomenon was related to the production of androgen hormone when Pasundan bulls reaching sexual maturity (Arifin et al., 2019; Wulandari et al., 2019). Body coat color is one of the critical aspects that determine the susceptibility of the individual livestock to heat stress. The individual livestock with dark or black coat color tended to be more impacted by heat stress (Brown-Brandl, 2013). In a study by (Hillman et al., 2005), Angus cattle, which had black hair coat color, had the highest solar absorption (81\%) as compared to MARC III, MARC I and Charolais cattle, which had dark red, tan and white hair coat color with solar absorption rate of 67,45 and $38 \%$, respectively. Van laer et al. (2014) also noticed that the livestock with dark coat color had lower heat tolerance due to the higher absorption rate of radiation. Therefore, it could be speculated that the black coat color of Pasundan bulls could elevate the indirect effect of solar radiation on heat stress. The existence of heat stress in bulls could deteriorate the spermatogenic cycle (Krishnan et al., 2017), which then could decrease sperm production, thus reducing sperm concentration. The decrease in sperm concentration was then also impacted on the decrease in total sperm number and frozen semen production.

\section{Conclusion}

It could be concluded that there are seasonal variations on the semen quality of Pasundan bulls in their native tropical environment. The semen quality of Pasundan bulls is notably reduced during the dry season, which is considerably associated with the higher sunshine duration at this time point. However, the reduction of semen quality is still tolerable and for that reason, the semen collection of Pasundan bulls is accepted to be done both in rainy and dry seasons.

\section{Acknowledgement}

The authors acknowledged Lembang Artificial Insemination Center for research facility support.

\section{Author's Contributions}

Nurul Isnaini: Conceptualization, research planning, data interpretation and manuscript preparation.

Tri Harsi: Conceptualization, research planning and data collection.

Anggit Damaratri Lapoliwa, Muhammad Mas'ud Chabiburochman and Abimarhadimas Dwi Amarsyah: Data collection, data analysis and manuscript preparation.

\section{Ethics}

The authors declare that there are no ethical issues may arise after the publication of this study.

\section{References}

Agus, A., \& Widi, T. S. M. (2018). Current situation and future prospects for beef cattle production in Indonesia-A review. Asian-Australasian Journal of Animal Sciences, 31(7), 976. https://doi.org/10.5713/ajas.18.0233

Argiris, A., Ondho, Y. S., Santoso, S. I., \& Kurnianto, E. (2018, February). Effect of age and bulls on fresh semen quality and frozen semen production of Holstein bulls in Indonesia. In IOP Conference Series: Earth and Environmental Science (Vol. 119, No. 1, p. 012033). IOP Publishing. https://doi.org/10.1088/1755-1315/119/1/012033.

Arifin, J., Komar, S. B., Indrijani, H., Daud, A. R., \& Kuswaryan, S. (2019). The Gene Distribution, Population Equilibrium, Effective Population Size of Pasundan Cattle in Village Breeding Centre at the Southern Part of West Java, Indonesia. KnE Life Sciences, 216-226. http://dx.doi.org/10.18502/kls.v4i11.3867

Bhakat, M., Mohanty, T. K., Raina, V. S., Gupta, A. K., Khan, H. M., Mahapatra, R. K., \& Sarkar, M. (2011). Effect of age and season on semen quality parameters in Sahiwal bulls. Tropical Animal Health and Production, 43(6), 1161-1168. https://doi.org/10.1007/s11250-011-9817-1

Brown-Brandl, T. M. (2013). Managing thermal stress in feedlot cattle: environment, animal susceptibility and management options from a US perspective. Livestock Housing: Modern Management to Ensure Optimal Health and Welfare of Farm Animals, 189. https://doi.org/10.3920/978-90-8686-771-4_10 
CDISA. (2017). Outlook Daging Sapi [Indonesian]. General Secretary Ministry of Agriculture, Jakarta, Indonesia. Central Data and Information System of Agriculture. http://epublikasi.setjen.pertanian.go.id/download/file /399-outlook-daging-sapi-2017

Chacur, M. G. M., Mizusaki, K. T., Gabriel Filho, L. R. A., Oba, E., \& Ramos, A. A. (2013). Seasonal Eff ects on Semen and Testosterone in Zebu and Taurine Bulls. Acta Scientiae Veterinariae, 41(1), 1-5. http://www.ufrgs.br/actavet/41/PUB\%201110.pdf

de Castro, S. R. S., Morini, A. C., da Silva, A. D. S. L., Neves, K. A. L., Minervino, A. H. H., de Moura Meneses, A. A., \& Vale, W. G. (2017). Influence of Seasonality on Buffalo Semen. Animal and Veterinary Sciences, $5(3)$,

45 . http://doi.org/10.11648/j.avs.20170503.12

DGLAH. (2014). Livestock and Animal Health Statistics 2014. Ministry of Agriculture, Jakarta, Indonesia. Directorate General of Livestock and Animal Health. https://ditjenpkh.pertanian.go.id/buku-statistikpeternakan-dan-kesehatan-hewan-tahun-2014

DGLAH. (2018). Livestock and Animal Health Statistics 2018. Ministry of Agriculture, Jakarta, Indonesia. Directorate General of Livestock and Animal Health. https://ditjennak.pertanian.go.id/buku-statistikpeternakan-dan-kesehatan-hewan-tahun-2018

Golher, D. M., Kumaresan, A., Saraf, K. K., Chhillar, S., Nayak, S., Tripathi, U. K., ... \& Mohanty, T. K. (2018). Influence of season and climatic variables on testicular cytology, semen quality and melatonin concentrations in crossbred bucks reared under subtropical climate. International Journal of Biometeorology, 62(9), 1709-1719. https://doi.org/10.1007/s00484-018-1571-x

Herbut, P., Angrecka, S., \& Walczak, J. (2018). Environmental parameters to assessing of heat stress in dairy cattle-a review. International Journal of Biometeorology, 62(12), 2089-2097. https://doi.org/10.1007/s00484-018-1629-9

Hillman, P. E., Gebremedhin, K. G., Brown-Brandl, T. M., \& Lee, C. N. (2005). Thermal analysis and behavioral activity of heifers in shade or sunlight. In Livestock Environment VII, 18-20 May 2005, Beijing, China (p. 151). American Society of Agricultural and Biological Engineers. http://doi.org/10.13031/2013.18360

Isnaini, N., Harsi, T., \& Maharani, D. (2019a). Seasonal effect on semen characteristics of Murrah buffalo bulls raised under tropical climate. Jurnal Kedokteran Hewan September, 13(3), 73-75. https://doi.org/10.21157/j.ked.hewan.v13i3.14627

Isnaini, N., Wahjuningsih, S., Ma'ruf, A., \& Witayanto, D. A. (2019b). Effects of age and breed on semen quality of beef bull sires in an Indonesian artificial insemination center. Livestock Research for Rural Development, $31(5)$. http://www.lrrd.org/lrrd31/5/nurul31078.html
Isnaini, N., Wahjuningsih, S., \& Adhitama, E. (2019c). Seasonal effects on semen quality of Ongole crossbred and Simmental bulls used for artificial insemination. Livestock Research for Rural Development, 31(2), 16. http://www.lrrd.org/lrrd31/2/nurul31016.html

Krishnan, G., Bagath, M., Pragna, P., Vidya, M. K., Aleena, J., Archana, P. R., ... \& Bhatta, R. (2017). Mitigation of the heat stress impact in livestock reproduction. Theriogenology, 8, 8-9. http://doi.org/10.5772/intechopen.69091

Landaeta-Hernández, A. J., Gil-Araujo, M. A., Ungerfeld, R., Rae, D. O., Urdaneta-Moyer, A., Parra-Núñez, A., ... \& Chenoweth, P. J. (2020). Effect of season and genotype on values for bull semen variables under tropical conditions. Animal Reproduction Science, 221 , 106592 . https://doi.org/10.1016/j.anireprosci.2020.106592

Mohammed, A. (2018). Artificial insemination and its economical significancy in dairy cattle: review. Int. J. Res. Stud. Microbiol. Biotechnol, 4(1), 30-43. https://dx.doi.org/10.20431/2454-9428.0401005

Moore, S. G., \& Hasler, J. F. (2017). A 100-Year Review: Reproductive technologies in dairy science. Journal of dairy science, 100(12), 10314-10331. https://doi.org/10.3168/jds.2017-13138

Mwangi, F. W., Charmley, E., Gardiner, C. P., Malau-Aduli, B. S., Kinobe, R. T., \& Malau-Aduli, A. E. (2019). Diet and genetics influence beef cattle performance and meat quality characteristics. Foods, 8(12), 648. https://doi.org/10.3390/foods8120648

Nichi, M., Bols, P. E. J., Züge, R. M., Barnabe, V. H., Goovaerts, I. G. F., Barnabe, R. C., \& Cortada, C. N. M. (2006). Seasonal variation in semen quality in Bos indicus and Bos taurus bulls raised under tropical conditions. Theriogenology, 66(4), 822-828. https://doi.org/10.1016/j.theriogenology.2006.01.056

Nongbua, T., Utta, A., Am-In, N., Suwimonteerabutr, J., Johannisson, A., \& Morrell, J. M. (2020). Effects of season and single layer centrifugation on bull sperm quality in Thailand. Asian-Australasian journal of Animal Sciences, 33(9), 1411. https://dx.doi.org/10.5713\%2Fajas.19.0624

Nugraha, C. D., Herwijanti, E., Novianti, I., Furqon, A., Septian, W. A., Busono, W., \& Suyadi, S. (2019). Correlations between age of Bali bull and semen production at National Artificial Insemination Center, Singosari-Indonesia. Journal of the Indonesian Tropical Animal Agriculture, 44(3), 258-260. https://doi.org/10.14710/jitaa.44.3.258-265

Perumal, P., Savino, N., Sangma, C. T. R., Khan, M. H., Ezung, E., Chang, S., \& Sangtam, T. Z. T. (2017). Seasonal effect on physiological, reproductive and fertility profiles in breeding mithun bulls. Asian Pacific Journal of Reproduction, 6(6), 268. http://journals.hainmc.edu.cn/apjr/article/pdf/20170606 
Prastowo, S., Kusuma, M. S. T., Widyas, N., Ratriyanto, A., Pramono, A., \& Setyawan, I. A. (2018, September). Effect of season on semen production and quality parameter in Indonesian Bali Cattle (Bos javanicus). In AIP Conference Proceedings (Vol. 2014, No. 1, p. 020005). AIP Publishing LLC. https://doi.org/10.1063/1.5054409

Ribas-Agustí, A., Díaz, I., Sárraga, C., García-Regueiro, J. A., \& Castellari, M. (2019). Nutritional properties of organic and conventional beef meat at retail. Journal of the Science of Food and Agriculture, 99(9), 4218-4225. https://doi.org/10.1002/jsfa.9652

Sabés-Alsina, M., Johannisson, A., Lundeheim, N., Lopez-Bejar, M., \& Morrell, J. M. (2017). Effects of season on bull sperm quality in thawed samples in northern Spain. Veterinary Record, 180(10), 251-251. https://doi.org/10.1136/vr.103897

Sabés-Alsina, M., Lundeheim, N., Johannisson, A., López-Béjar, M., \& Morrell, J. M. (2019). Relationships between climate and sperm quality in dairy bull semen: A retrospective analysis. Journal of Dairy Science, 102(6), 5623-5633. https://doi.org/10.3168/jds.2018-15837

Said, S., Putra, W. P. B., Anwar, S., Agung, P. P., \& YUHANI, H. (2017). Phenotypic, morphometric characterization and population structure of Pasundan cattle at West Java, Indonesia. Biodiversitas Journal of Biological Diversity, 18(4), 1638-1645. https://doi.org/10.13057/biodiv/d180443

Setiawati, E. N., Saleh, D. M., \& Sumaryadi, M. Y. (2018, December). Kinerja reproduksi sapi Pasundan di Jawa Barat. In Prosiding seminar teknologi agribisnis peternakan (stap) fakultas peternakan universitas jenderal soedirman (Vol. 6, pp. 158-167) http://jnp.fapet.unsoed.ac.id/index.php/psv/article /view/150

SNI 4869-1:2008. (2008). Semen Beku-Bagain 1: Sapi [Indonesian]. National Standardization Agency of Indonesia, Jakarta, Indonesia. https://docplayer.info/33119173-Semen-bekubagian-1-sapi.html

Snoj, T., Kobal, S., \& Majdic, G. (2013). Effects of season, age and breed on semen characteristics in different Bos taurus breeds in a 31-year retrospective study. Theriogenology, 79(5), 847-852. https://doi.org/10.1016/j.theriogenology.2012.12.014
Sulasmi, A. G., Priyanto, R., Sumantri, C., \& Arifin, J. (2017). Keseragaman dan kedekatan morfometrik ukuran tubuh sapi pasundan. Jurnal Veteriner, 18(2), 263-273 https://doi.org/10.19087/jveteriner.2017.18.2.263

Suretno, N. D., Supriyatna, I., Purwanto, B., \& Priyanto, R. (2018). Reproductive performance of peranakan ongole (PO) bull at different altitudes areas in Lampung province. In IOP Conference Series: Earth and Environmental Science (Vol. 102, No. 1, p. 012020). IOP Publishing. https://doi.org/10.1088/17551315/102/1/012020

Susilawati, T. R. I. N. I. L., Ratnawati, D. I. A. N., Isnaini, N. U. R. U. L., Kuswati, K., \& Yekti, A. P. (2018). Character of liquid semen motility in various diluents on Balinese cattle during cold storage. Asian Journal of Microbiology, Biotechnology and Environmental Sciences, 20(1), 166-172. http://www.envirobiotechjournals.com/article_abstra ct.php?aid=8497\&iid=244\&jid=1

Sutarno, S., \& Setyawan, A. D. (2015). Genetic diversity of local and exotic cattle and their crossbreeding impact on the quality of Indonesian cattle. Biodiversitas Journal of Biological Diversity, 16(2). https://doi.org/10.13057/biodiv/d160230

Valeanu, S., Johannisson, A., Lundeheim, N., \& Morrell, J. M. (2015). Seasonal variation in sperm quality parameters in Swedish red dairy bulls used for artificial insemination. Livestock Science, 173, 111-118. https://doi.org/10.1016/j.livsci.2014.12.005

Van laer, E., Moons, C. P. H., Sonck, B., \& Tuyttens, F. A. M. (2014). Importance of outdoor shelter for cattle in temperate climates. Livestock Science, 159, 87-101. https://doi.org/10.1016/j.livsci.2013.11.003

Wulandari, A., Nurgiartiningsih, V. M. A., Kuswati, Susilorini, T. E., \& Partogi. P. A. (2019). Kinship of Several Indonesian Local Cattles by Using DNA Mitochondrial COI (Cytochrome Oxidase Sub-unit I). $\quad$ Science, 4(3), 165-167. http://doi.org/10.5281/zenodo.3360536

Yekti, A. P. A., Tatulus, W. S. S., Ratnawati, D., Affandhy, L., Kuswati, K., Huda, A. N., \& Susilawati, T. (2018). Kualitas dan kapasitasi spermatozoa sapi bali, madura, dan peranakan ongole. Jurnal Ilmu dan Teknologi Peternakan Tropis, 5(2), 34-41. http://dx.doi.org/10.33772/jitro.v5i2.4739 